\title{
Insight into the Willgerodt-Kindler Reaction of $\omega$-Haloacetophenone Derivatives: Mechanistic Implication
}

\author{
Urbain C. Kasséhin, ${ }^{1,2}$ Fernand A. Gbaguidi, ${ }^{1}$ Coco N. Kapanda, ${ }^{3}$ \\ Christopher R. McCurdy, ${ }^{3}$ and Jacques H. Poupaert ${ }^{2}$ \\ ${ }^{1}$ Laboratoire de Chimie Pharmaceutique Organique, Ecole de Pharmacie, Faculté des Sciences de la Santé, \\ Université d'Abomey-Calavi, Campus du Champ de Foire, 01 BP 188 Cotonou, Benin \\ ${ }^{2}$ Medicinal Chemistry, Louvain Drug Research Institute, UCL, 73 Bte B1.73.10, Avenue E. Mounier, 1200 Bruxelles, Belgium \\ ${ }^{3}$ Department of BioMolecular Sciences, School of Pharmacy, University of Mississippi, 419 Faser Hall, P.O. Box 1848, \\ University, MS 38677-1848, USA \\ Correspondence should be addressed to Urbain C. Kasséhin; comlan.kassehin@student.uclouvain.be
}

Received 16 September 2014; Accepted 25 November 2014; Published 10 December 2014

Academic Editor: Joseph E. Saavedra

Copyright (C) 2014 Urbain C. Kasséhin et al. This is an open access article distributed under the Creative Commons Attribution License, which permits unrestricted use, distribution, and reproduction in any medium, provided the original work is properly cited.

\begin{abstract}
This paper reports efforts aimed at tuning up the synthesis of a compound library centered on the general template 2amino-1-phenyl-2-thioxoethanone taking the condensation of $\omega$-haloacetophenone, octasulfur, and morpholine as pilot reaction. Considerations about atomic economy were found extremely precious in selecting the best starting halo-reagent. A one-pot practical method based on use of 2-bromo-1-phenylethanone as substrate and $N, N$-dimethylformamide as solvent can be easily scaled up to gram amounts (72\% yield). Based on this synthetic approach, some more specific examples are reported.
\end{abstract}

\section{Introduction}

Thioamides and related structure are ever more becoming essential building blocks for preparing biologically useful probes [1]. Along this line, a plethora of methods has long been reported in the literature to synthesize thioamides $[2,3]$. In spite of the fact that this one-pot process is a long-known reaction (which was first reported by Kindler in 1923) [4], the three-component condensation of an aldone (aldehydeketone) $\mathbf{1}$, cyclooctasulfur (i.e., cyclo- $\mathrm{S}_{8}$ ), and an amine $\mathbf{2 -}$ either primary or secondary-(Figure 1), termed nowadays in the literature as the Willgerodt-Kindler (WK) reaction, has received over the last ten years considerable attention, from the point of view of the combinatorial chemistry [5, 6]. There has been indeed a revival of interest for this relatively old reaction as it allows for a straightforward introduction of chemical diversity around the $\mathrm{C}(=\mathrm{S})-\mathrm{NH}$ backbone by variation of the aldone $\left(\mathrm{R}^{1}\right)$ and amine $\left(\mathrm{R}^{2}\right.$ and $\mathrm{R}^{3}$ ) components in a one-pot single condensation step [7]. As a wide variety of aldones and primary/secondary amines are nowadays readily commercially accessible, as a consequence a wide variety of pharmacologically useful thioamides can thus be potentially prepared in a single-step procedure using this method $[2,8,9]$. It is also noteworthy that the WK reaction allows for a form of "umpolung" which involves the reversal of polarity, in the sense that, starting from the acetophenone substrate, for example, the carbonyl is reduced while the terminal methyl group is oxidized.

In this connection, and particularly in the context of the synthesis of a compound library, our group became interested in generating a collection of 2-oxo-2-phenylethanethioamide derivatives as potential inhibitors of the endocannabinoid MAGL (monoacylglycerol lipase) enzyme for high throughput screening [10-14]. The general structure of the targeted molecules is shown in Figure 2. This paper thus reports our efforts aimed at tuning up a model reaction in the elaboration of a compound library centered on the general template 2amino-1-phenyl-2-thioxoethanone taking into consideration the condensation of $\omega$-haloacetophenone, octasulfur, and morpholine as pilot reaction. For obvious reasons, the fluoro 
<smiles>[X]c1ccccc1NC(=S)N([R])[R]</smiles>

Figure 1: General equation of the WK reaction (where $\mathrm{X}$ is a substituent on the aryl group, $n$ is a variable number of methylene groups, and $\mathrm{R}$ and $\mathrm{R}^{\prime}$ are alkyl, aryl, or (hetero)cycloalkyl groups).

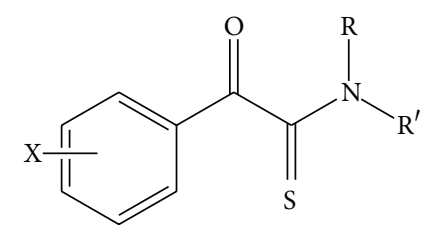

FIGURE 2: General template of $\alpha$-ketothioamides reaction (where $\mathrm{X}$ is a substituent on the aryl group and $\mathrm{R}$ and $\mathrm{R}^{\prime}$ are alkyl, aryl, or (hetero)cycloalkyl groups).

term was not considered in this study because of its too low intrinsic reactivity; the iodo term was also eliminated because of its chemical instability. As a matter of fact, many synthetic alternatives refering to $\alpha$-ketothioamides were already published in the literature. However, these approaches mostly, not generally, employ hazardous and expensive reagents and necessitate long reactions times. Nevertheless, some of the most recent literature references demonstrate the contemporary relevance of this class of molecules. Some of these recent contributions capitalize on arylglyoxal derivatives as starting materials, which are synthetized from acetophenones exploiting selenium dioxide as oxidizing agent. This reagent however is toxic as well as the selenious acid found in the effluents after working up the reaction mixture to isolate the glyoxal derivatives. This can be alleviated by using our halogenation procedure herein described [15-17].

\section{Results and Discussion}

Increasingly stringent environmental and economic considerations along with paradigms generated a pressing need for cleaner and more efficient methods of chemical synthesis, which reduce amounts of waste and avoid the use of toxic and potentially hazardous reagents and solvents [18-20]. This trend toward "green chemistry" [21, 22] requires a form of separation from the traditional concepts which focusses on chemical yields to one that drastically aims at limiting unuseful wastes. Along this line was introduced the concept of "atomic economy."

Atomic economy (AE) can be written as in the following equation:

$$
\mathrm{AE}(\%)=\frac{\mathrm{MW}(\text { end product })}{\Sigma(\mathrm{MW} \text { reactants })} \times 100
$$

The atom economy (AE) concept [19] is an extremely useful tool for rapid assessment of the amount of waste generated in the synthesis of a reaction product. It is calculated by
TABLE 1: Atomic economy for the model WK reaction.

\begin{tabular}{lcccc}
\hline Entry & $\mathrm{R}$ & $\begin{array}{c}\text { Atom } \\
\text { economy (\%) }\end{array}$ & $\begin{array}{c}\text { Yield } \\
(\%)\end{array}$ & $\begin{array}{c}\text { Overall } \\
\text { efficiency }\end{array}$ \\
\hline (Number 1) & $\mathrm{CH}_{3}$ & 98 & 2.7 & 2.6 \\
(Number 2) & $\mathrm{CH}_{2} \mathrm{Cl}$ & 86 & 40 & 34 \\
(Number 3) & $\mathrm{CHCl}_{2}$ & 76 & 65 & 49 \\
(Number 4) & $\mathrm{CH}_{2} \mathrm{Br}$ & 74 & 72 & 53 \\
(Number 5) & $\mathrm{CHBr}_{2}$ & 59 & 70 & 41 \\
\hline
\end{tabular}

dividing the molecular weight of the end product by the sum of the molecular weights (MW) of all reactants involved in the stoechiometric equation for the reaction(s) considered, this ratio being multiplied by 100 (1). Typically, catalytic hydrogenation of an alkene, for instance, reduction of styrene to ethylbenzene using dihydrogene, has got an $\mathrm{AE}$ of $100 \%$. Diels-Alder reaction is another example also that has got a $100 \%$ AE. Calculation of the atom economy has been performed for various pertinent model reactions of the WK reaction and the results are shown in Table 1 (cfr Figure 3).

Clearly, the best AE figure is reached with acetophenone (entry number 1) whereas the less efficient option is obtained for 2,2-dibromo-1-phenylethanone (entry number 5). However, this aspect must be tempered by the actual yield of the reaction. In our hands, preliminary results indicated that 2-bromo-1-phenylethanone (entry number 4) was the best substrate for the reaction in terms of yield and also ease of reaction. In effect, if we multiply the AE value by the actual yield to obtain the overall efficiency, entry number 4 appears as the best practical option. The dibromo (entry number 5) substrate is too reactive and requires cooling at the beginning of the reaction. For all these reasons, we therefore endeavour to obtain a one-pot practical method that could be easily scaled up to gram scale amounts.

After carrying out directly the bromination of acetophenone in a traditional manner (see Section 4.1) in chloroform, the resulting product was engaged in the WK process without any further purification. Following stepwise optimization, ingredients necessary to perform the WK reaction were introduced into the reaction medium in the following order: DMF, octasulfur (1.5 equivalents), and finally morpholine (3 equivalents). The reaction proceeded to completion at room temperature in $24 \mathrm{~h}$. Using excess sulfur does not create a problem with regard to the purity of the final product as far as the amine is also used in sufficient excess (here 3 equivalents) and therefore these side-products are easily removed during the work-up. The reactive intermediates involved in the WK reaction are indeed in great part polar water-soluble nitrogen-sulfur species formed by ring opening of octasulfur by the nucleophilic attack of the amine [23]. DMF (at room temperature) was found greatly beneficial as reaction in refluxing diethyl ether $\left(\sim 35^{\circ} \mathrm{C}\right)$ required a rather long reaction time, typically $36 \mathrm{~h}$.

At this point, the question arose as to the genesis of compound (5) starting from acetophenone (1). According to Liu et al. [24], there would be apparently a spontaneous formation of 2-morpholino-1-phenylethanone (6) (cfr Figure 5) from 
<smiles>[R]C(=O)c1ccccc1</smiles>

Figure 3: WK pilot reaction.<smiles>CC(=O)c1ccccc1</smiles>

(1)<smiles>O=C(C=S)c1ccccc1</smiles>

(2)<smiles>O=C(C(=S)N1CCOCC1)c1ccccc1</smiles>

(5)<smiles>O=C(C=[N+]1CCOCC1)c1ccccc1</smiles>

(3)<smiles>O=C(C(S)=[N+]1CCOCC1)c1ccccc1</smiles>

(4)

FIGURE 4: Mechanism proposed for the generation of 2-oxo-2-phenylethanethioamide (5) from acetophenone (1).<smiles>O=C(CN1CCOCC1)c1ccccc1</smiles>

Figure 5

acetophenone by direct substitution on the methyl group. This seems very unlikely as this process (SN2 nucleophilic substitution) would formally involve the release of a hydride anion and a strong base and therefore represents a pretty bad "leaving group." We therefore sought for an alternative mechanistic explanation which is shown in Figure 4. In this mechanism proposal, $\mathbf{1}$ is thionated to a thioaldehyde species (2) which is transformed to an immonium species (3) by nucleophilic attack and condensation with morpholine. Further thionation of (3) leads to (4) which after loss of a hydron yields final compound (5). It should be noted that thionation of active methylene moieties is classically invoked in the WK reaction and other related chemical situations [23]. Moreover, it is worth mentioning that in this reaction in which (5) is produced there is a massive production of the normal WK product which is the expected phenylthiomorpholide $[4,8]$.

As to the possibility that at the level of compound (2) there would be potentially a concurrent nucleophilic attack of the secondary amine onto the carbonyl in 2position, a possibility that cannot be theoretically excluded, we performed various attempts to react this carbonyl at the level of compound (5), using primary and secondary amines without any success. In this connection, it should be pointed out that 4-phenylthiosemicarbazide is a reagent well known for its high nucleophilicity and affinity for carbonylated compounds. Furthermore, (5) remained inert towards 4-phenylthiosemicarbazide even under strong conditions. We can therefore state that this carbonyl group is strongly deactivated presumably due to the neighbouring thiocarbonyl group.

To further substantiate our approach, we report the synthesis of a few terms of the projected library which were obtained in good yield (typically 70\% yield). Further work is now being devoted to create a compound library of $\alpha$-ketothioamides in the antitrypanosomal (Trypanosoma brucei brucei) axis.

\section{Conclusion}

In this paper, we report efforts aimed at tuning up the synthesis of a series of 2-amino-1-phenyl-2-thioxoethanone based on the condensation of $\omega$-haloacetophenone, octasulfur, and morpholine with special consideration about atomic economy and efficiency. A one-pot practical method based on use of 2-bromo-1-phenylethanone as substrate and DMF as solvent has been set up. It is noteworthy that this synthetic method proceeds in good yield at room temperature, in contrast with the need for high temperatures in most WK processes. Hendrickson defined such a synthesis in 1975, stating that "The ideal synthesis creates a complex molecule in a sequence of only construction reactions involving no intermediary refunctionalizations, leading directly to the target, not only its skeleton but also its correctly placed functionality" [25]. In this connection, we truly believe pragmatically that the WK reaction applied to haloacetophenones 
is a remarkable example of a reaction to be included among ideal syntheses.

\section{Experimental}

Melting points were determined using an electrothermal melting point apparatus and are uncorrected. IR spectra were recorded on a Perkin-Elmer 457 spectrometer using $\mathrm{KBr}$ pellets. Wave numbers are expressed in $\mathrm{cm}^{-1} \cdot{ }^{1} \mathrm{H}$ - and ${ }^{13} \mathrm{C}$-NMR spectra were recorded at ambient temperature on a Brucker 400 spectrometer. Compounds were dissolved in $\mathrm{CDCl}_{3}$ or DMSO-d6 to obtain a 0.1 molar solution. Chemical shifts are expressed in the $\delta$ scale with TMS (tetramethylsilane) as internal standard. Thin layer chromatography (TLC) analyses were performed on Merck TLC plates (silica gel, 60 F 254, E. Merck, Darmstadt, ref. 5735). For TLC, all the compounds reported were routinely checked in two standard solvents, that is, acetone/toluene/cyclohexane (solvent A, $5: 2: 3, \mathrm{v} / \mathrm{v} / \mathrm{v}$ ) and ethyl acetate/n-hexane (solvent $\mathrm{B}, 4: 6, \mathrm{v} / \mathrm{v})$. The reverse-phase thin layer chromatography conditions were HPTLC plates RP-18 F-254 S (Merck) and methanol: water $(75 / 25, \mathrm{v} / \mathrm{v})$. All compounds reported were found homogenous under such TLC and HPLC conditions. All reagents were purchased from Aldrich. All solvents were of the ACS reagent grade (Aldrich).

4.1. 2-Morpholino-1-phenyl-2-thioxoethanone (5). To a magnetically stirred solution of acetophenone $(12.0 \mathrm{~g}, 0.1 \mathrm{~mol})$ in ethanol-stabilized chloroform $(50 \mathrm{~mL})$ was added dropwise over $30 \mathrm{~min}$ a solution of dibromine $(19.2 \mathrm{~g}, 0.12 \mathrm{~mol}$ ) in chloroform $(25 \mathrm{~mL})$. The reaction vessel was partially immersed in a water bath $\left(\sim 20^{\circ} \mathrm{C}\right)$ to cool down some heat evolution. After $2 \mathrm{~h}$, the solvent was evaporated in vacuo to give a crude yellowish oil consisting mainly of 2bromo-1-phenylethanone along with trace amounts of 2,2dibromo-1-phenylethanone according to ${ }^{13} \mathrm{C}-\mathrm{NMR}$ analysis. To this oily residue were added at room temperature in sequence DMF $(15 \mathrm{~mL})$, cyclooctasulfur $(4.8 \mathrm{~g}, 0.15 \mathrm{~mol})$, and vacuum-redistilled morpholine $(26.1 \mathrm{~g}, 0.3 \mathrm{~mol})$. Some moderate heat evolution was noted. The reaction mixture was stirred magnetically and kept at room temperature for $24 \mathrm{~h}$, quenched with distilled water $(250 \mathrm{~mL})$ to give a semisolid precipitate which was further washed twice with distilled water $(100 \mathrm{~mL})$. The resulting hard cake was crystallized from absolute ethanol using a Soxhlet solid-liquid extraction apparatus to remove any unreacted sulfur and give TLC pure (solvent B, Rf 0.65) pure 2-morpholino-1-phenyl-2thioxoethanone (18.2 g, 72\% yield). m.p. $112-113^{\circ} \mathrm{C} ;{ }^{1} \mathrm{H}$ NMR $\left(\mathrm{CDCl}_{3}, 400 \mathrm{MHz}\right) \delta: 8.02-7.48(\mathrm{~m}, \mathrm{Ph}, 5 \mathrm{H}), 4.38-4.33$ (m, $\left.\mathrm{OCH}_{2}, 2 \mathrm{H}\right), 3.96-3.90\left(\mathrm{~m}, \mathrm{OCH}_{2}, 2 \mathrm{H}\right), 3.73-3.68\left(\mathrm{~m}, \mathrm{NCH}_{2}\right.$, 2H), 3.64-3.59 (m, $\left.\mathrm{NCH}_{2}, 2 \mathrm{H}\right)$; IR (KBr) v: 3060, 2971, 2855, $1667(\nu \mathrm{C}=\mathrm{O}), 1594,1579,1450(\nu \mathrm{C}=\mathrm{S}), 1106,701,688 \mathrm{~cm}^{-1}$; ${ }^{13}$ C-NMR DMSO-d6, 100.6 MHz $\delta 44.77,49.58,64.01,64.12$, 126.61, 127.47, 130.91, 132.09, $185.52(\mathrm{C}=\mathrm{O}), 193.32(\mathrm{C}=\mathrm{S})$; MS m/z (\%): 235 (M+, 35), 221 (5), 177 (20), 150 (4), 130 (91), 105 (84), 86 (100), 77(62), 43 (31).
4.2. N-Benzyl-N-methyl-2-oxo-2-phenylethanethioamide (6). m.p. $107-18^{\circ} \mathrm{C}$; TLC (solvent B, Rf 0.60); IR (KBr) v: 3062, 2933, 1667 ( $\nu \mathrm{C}=\mathrm{O}), 1595,1579,1450$ ( $\nu \mathrm{C}=\mathrm{S}) ;{ }^{1} \mathrm{HNMR}$ $\left(\mathrm{CDCl}_{3}\right): \delta(\mathrm{ppm}) 7.24-8.03(\mathrm{~m}, 10 \mathrm{H}), 3.37(\mathrm{~s}, 2 \mathrm{H}) 3.06(\mathrm{~s}$, $3 \mathrm{H}){ }^{13} \mathrm{CNMR}\left(\mathrm{CDCl}_{3}\right): \delta(\mathrm{ppm}) 195.95(\mathrm{C}=\mathrm{S}), 186.68(\mathrm{C}=\mathrm{O})$, $133.19,132.31,132.00,128.89,128.80,128.64,127.76,127.53$, $126.85,45.87,38.25$.

\subsection{2-(4-Benzhydrylpiperazin-1-yl)-1-phenyl-2-thioxoetha-}

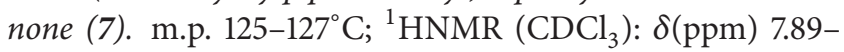
$7.22(\mathrm{~m}, 15 \mathrm{H}), 4.22(\mathrm{~s}, 1 \mathrm{H}) 3.51(\mathrm{t}, 2 \mathrm{H}, J=4.84 \mathrm{~Hz}), 3.49(\mathrm{t}$, $2 \mathrm{H}, J=4.76 \mathrm{~Hz}), 2.56(\mathrm{t}, 2 \mathrm{H}, J=4.84 \mathrm{~Hz}), 2.35(\mathrm{t}, 2 \mathrm{H}, J=$ $4.76 \mathrm{~Hz})$.

${ }^{13} \mathrm{CNMR}\left(\mathrm{CDCl}_{3}\right): \delta(\mathrm{ppm}) 195.05(\mathrm{C}=\mathrm{S}), 188.00(\mathrm{C}=\mathrm{O})$, $141.60,134.27,133.34,129.83,128.89,128.78,127.75,127.44$, 75.58, 51.75, 51.68, 51.12, 46.99. MS: $m / z=401.166$.

4.4. 2-(4-Benzhydrylpiperazin-1-yl)-1-(4-nitrophenyl)-2-thioxoethanone (8). m.p. $105-107^{\circ} \mathrm{C} ;{ }^{1} \mathrm{HNMR}\left(\mathrm{CDCl}_{3}\right): \delta(\mathrm{ppm})$ $8.29(\mathrm{~d}, 2 \mathrm{H}, J=8.52 \mathrm{~Hz}), 8.12(\mathrm{~d}, 2 \mathrm{H}, J=8.52 \mathrm{~Hz}), 7.41-$ $7.22(\mathrm{~m}, 10 \mathrm{H}), 5.27(\mathrm{~s}, 1 \mathrm{H}), 4.30(\mathrm{t}, 2 \mathrm{H}, J=4.44 \mathrm{~Hz}), 3.60$ $(\mathrm{t}, 2 \mathrm{H}, J=4.48 \mathrm{~Hz}), 2.44(\mathrm{t}, 2 \mathrm{H}, J=4.72 \mathrm{~Hz}), 2.65(\mathrm{t}, 2 \mathrm{H}$, $J=4.72 \mathrm{~Hz}) .{ }^{13} \mathrm{CNMR}\left(\mathrm{CDCl}_{3}\right): \delta(\mathrm{ppm}) 193.08(\mathrm{C}=\mathrm{S}), 184.57$ $(\mathrm{C}=\mathrm{O}), 150.69,141.41,138.47,130.77,128.82,127.74,127.52$, 123.98, 75.55, 51.91, 51.76, 51.10, 47.21. MS: $m / z=446.151$.

\section{Conflict of Interests}

The authors declare that there is no conflict of interests regarding the publication of this paper.

\section{References}

[1] J. Boström, R. I. Olsson, J. Tholander et al., "Novel thioamide derivatives as neutral CB1 receptor antagonists," Bioorganic \& Medicinal Chemistry Letters, vol. 20, no. 2, pp. 479-482, 2010.

[2] O. I. Zbruyev, N. Stiasni, and C. O. Kappe, "Preparation of thioamide building blocks via microwave-promoted threecomponent kindler reactions," Journal of Combinatorial Chemistry, vol. 5, no. 2, pp. 145-148, 2003.

[3] Z. Kaleta, B. T. Makowski, T. Soós, and R. Dembinski, "Thionation using fluorous Lawesson's reagent," Organic Letters, vol. 8, no. 8, pp. 1625-1628, 2006.

[4] K. Kindler, "Studien über den Mechanismus chemischer Reaktionen. Erste Abhandlung. Reduktion von Amiden und Oxydation von Aminen," Justus Liebigs Annalen der Chemie, vol. 431, pp. 187-230, 1923.

[5] K. Okamoto, T. Yamamoto, and T. Kanbara, "Efficient synthesis of thiobenzanilides by Willgerodt-Kindler reaction with base catalysts," Synlett, no. 17, pp. 2687-2690, 2007.

[6] F. A. Gbaguidi, C. N. Kapanda, A. L. Ahoussi et al., "General acid-base catalysis in the Willgerodt-Kindler reaction," Journal de la Société Ouest-Africaine de Chimie, vol. 029, pp. 89-94, 2010.

[7] H. R. Darabi, K. Aghapoor, Y. Balavar, E. Mobedi, H. Farhangian, and F. Mohsenzadeh, "Synthesis of 1,n-acyloxy thioamides by the Willgerodt-Kindler reaction: chemoselectivity of 1,3-ketoesters over 1,3-diketones," Zeitschrift fur Naturforschung, vol. 63, no. 8, pp. 993-997, 2008. 
[8] J. H. Poupaert, S. Duarte, E. Colacino, P. Depreux, C. R. McCurdy, and D. L. Lambert, "Willgerodt-kindler's microwaveenhanced synthesis of thioamide derivatives," Phosphorus, Sulfur and Silicon and the Related Elements, vol. 179, no. 10, pp. 1959-1973, 2004.

[9] J. H. Poupaert, P. Carato, and C. R. McCurdy, "A simple and effective method for the thionation of amides to thioamides using $\mathrm{Al}_{2} \mathrm{O}_{3}$-supported $\mathrm{P}_{4} \mathrm{~S}_{10}$, Letters in Organic Chemistry, vol. 2, no. 4, pp. 330-333, 2005.

[10] C. N. Kapanda, J. H. Poupaert, and D. M. Lambert, "Insight into the medicinal chemistry of the endocannabinoid hydrolase inhibitors," Current Medicinal Chemistry, vol. 20, no. 14, pp. 1824-1846, 2013.

[11] C. N. Kapanda, J. Masquelier, G. Labar, G. G. Muccioli, J. H. Poupaert, and D. M. Lambert, "Synthesis and pharmacological evaluation of 2,4-dinitroaryldithiocarbamate derivatives as novel monoacylglycerol lipase inhibitors," Journal of Medicinal Chemistry, vol. 55, no. 12, pp. 5774-5783, 2012.

[12] C. N. Kapanda, G. G. Muccioli, G. Labar, N. Draoui, D. M. Lambert, and J. H. Poupaert, "Search for monoglyceride lipase inhibitors: synthesis and screening of arylthioamides derivatives," Medicinal Chemistry Research, vol. 18, no. 4, pp. 243-254, 2009.

[13] G. Labar, C. Bauvois, G. G. Muccioli, J. Wouters, and D. M. Lambert, "Disulfiram is an inhibitor of human purified monoacylglycerol lipase, the enzyme regulating 2-arachidonoylglycerol signaling," ChemBioChem, vol. 8, no. 11, pp. 1293-1297, 2007.

[14] G. Labar and C. Michaux, "Fatty acid amide hydrolase: from characterization to therapeutics," Chemistry and Biodiversity, vol. 4, no. 8, pp. 1882-1902, 2007.

[15] J. E. Valdez-Rojas, H. Ríos-Guerra, A. L. Ramírez-Sánchez et al., "A study of the Willgerodt-Kindler reaction to obtain thioamides and $\alpha$-ketothioamides under solvent-less conditions," Canadian Journal of Chemistry, vol. 90, no. 7, pp. 567-573, 2012.

[16] B. Eftekhari-Sis, S. V. Khajeh, and O. Büyükgüngör, "Synthesis of $\alpha$-ketothioamides via willgerodt-kindler reaction of arylglyoxals with amines and sulfur under solvent-free conditions," Synlett, vol. 24, no. 8, pp. 977-980, 2013.

[17] H. Saeidian, S. Vahdati-Khajehi, H. Bazghosha, and Z. Mirjafary, "Na2S-mediated thionation: an efficient access to secondary and tertiary $\alpha$-ketothioamides via Willgerodt-Kindler reaction of readily available arylglyoxals with amines," Journal of Sulfur Chemistry, vol. 35, no. 6, pp. 700-710, 2014.

[18] G. Labar, F. V. Vliet, J. Wouters, and D. M. Lambert, "A MBPFAAH fusion protein as a tool to produce human and rat fatty acid amide hydrolase: expression and pharmacological comparison," Amino Acids, vol. 34, no. 1, pp. 127-133, 2008.

[19] R. A. Sheldon, "Atom efficiency and catalysis in organic synthesis," Pure and Applied Chemistry, vol. 72, no. 7, pp. 1233-1246, 2000.

[20] R. A. Sheldon, "Catalysis and zeolites: fundamentals and applications," Journal of Molecular Catalysis A, vol. 107, pp. 75-258, 1996.

[21] R. A. Sheldon, "Green chemistry and catalysis," Chemistry and Industry, pp. 903-906, 1992.

[22] R. A. Sheldon, "Green Chemistry for Environmental Sustainability Catalysis: the key to waste minimization," Journal of Chemical Technology and Biotechnology, vol. 68, no. 4, pp. 381388, 1997.
[23] M. Carmack, "The Willgerodt-Kindler reactions: the mechanism," Journal of Heterocyclic Chemistry, vol. 26, no. 5, pp. 13191323, 1989.

[24] W.-W. Liu, Y.-Q. Zhao, R.-B. Xu, L.-J. Tang, and H.-W. Hu, "An unexpected discovery in the Willgerodt-Kindler reaction of acetophenone-the formation of the 4-(benzoylthiocarbonyl)morpholine," Chinese Journal of Chemistry, vol. 24, no. 10, pp. 1472-1475, 2006.

[25] J. B. Hendrickson, "Systematic synthesis design. III. The scope of the problem," Journal of the American Chemical Society, vol. 97, no. 20, pp. 5763-5784, 1975. 

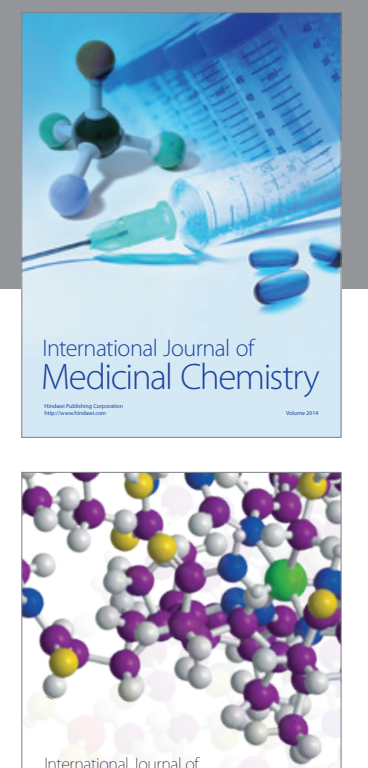

\section{Carbohydrate} Chemistry

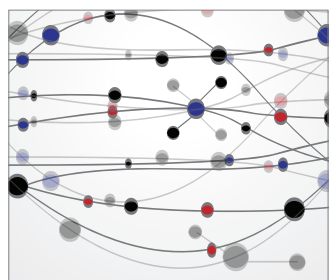

The Scientific World Journal
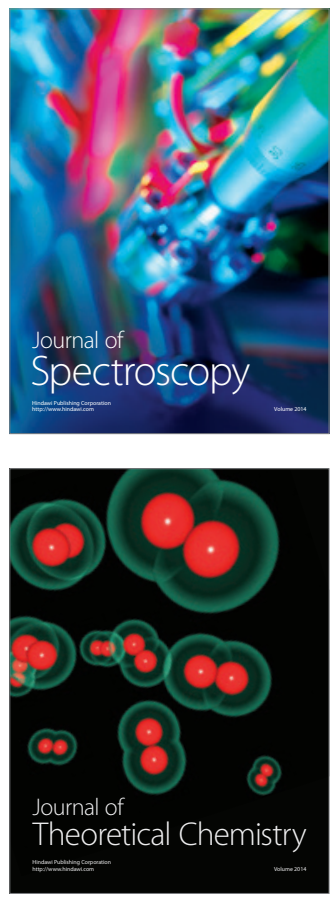
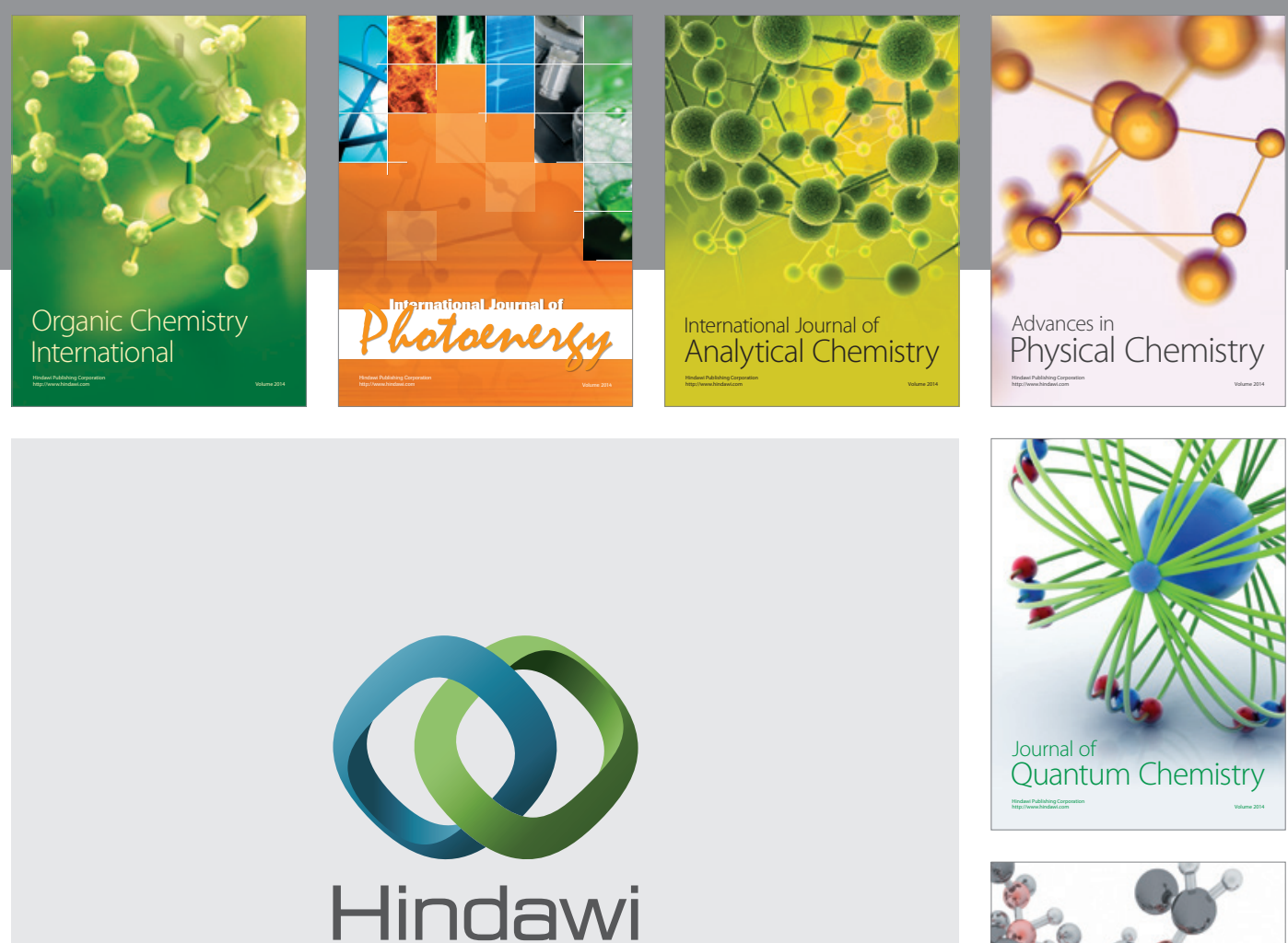

Submit your manuscripts at

http://www.hindawi.com

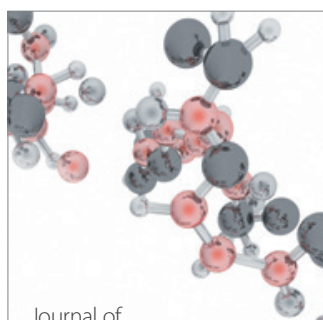

Analytical Methods

in Chemistry

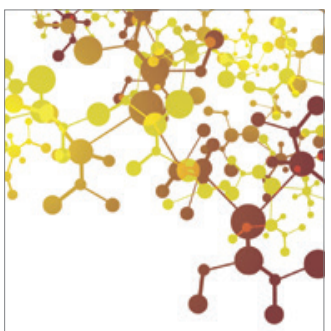

Journal of

Applied Chemistry

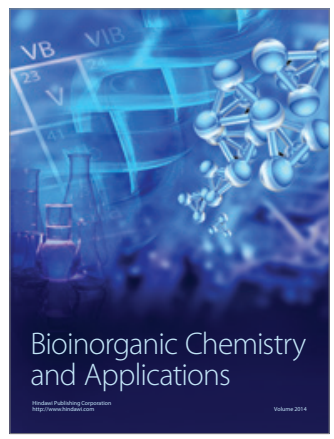

Inorganic Chemistry
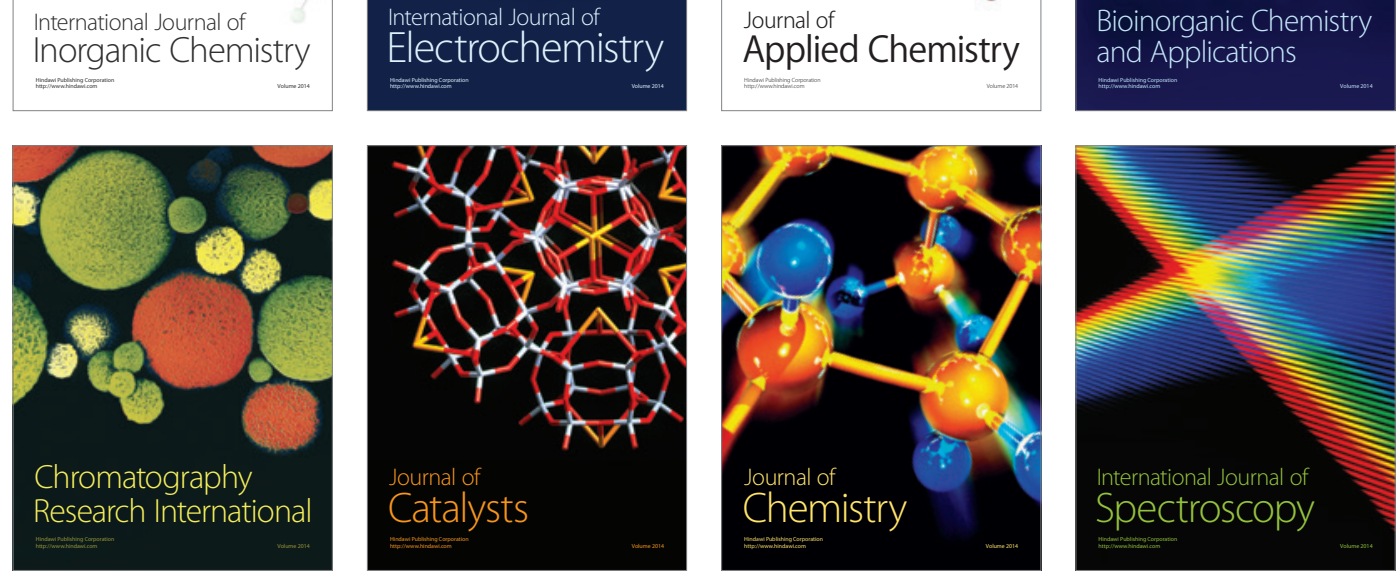